\title{
The Effect of Flooded Mine Subsidence on Thrips and Forest Biodiversity in the Silesian Upland of Southern Poland - A Case Study
}

\author{
E. SIERKA ${ }^{1 *}$ and W. SIERKA ${ }^{2}$ \\ ${ }^{1}$ Department of Geobotany and Nature Protection, Faculty of Biology and Environmental Protection, \\ University of Silesia, Jagiellońska 28, 40-032 Katowice, Poland \\ ${ }^{2}$ Department of Zoology, Faculty of Biology and Environmental Protection, University of Silesia, \\ Bankowa 9, 40-007 Katowice, Poland; e-mail: wojciech.sierka@us.edu.pl
}

(Received: 4 March 2008; accepted: 6 June 2008)

\begin{abstract}
At the end of the prosperity of the coal mining industry in Upper Silesia in Poland, new habitats were created in disturbed areas which, in the case of flooded mine subsidence, led to the formation of a type of ecological niche not encountered before. In the present work the authors describe the diversity of oak-hornbeam forest in the areas of flooded mine subsidence and the thrips communities connected with them. In 2006 and 2007, the thrips fauna of subsidence areas was sampled in biotopes directly associated with depressions (waterside, contact zones between aquatic and terrestrial - forest biotopes). In both ecosystems a total of 118 plant species and 56 thrips species were found. Disturbance of land resulting in flooded mine subsidence contributes to increased species diversity of both plants and thrips. Other kinds of disturbance such as traffic routes and its direct and indirect impact cause reduce numbers of plants and thrips species.
\end{abstract}

Keywords: thrips, Thysanoptera, flooded mine subsidence, biodiversity.

Flooded mine subsidence is one of the effects of underground hard coal mining. It results from the gradual sinking of the ground over the working and takes the form of shallow (3-4 m deep) basins with gently sloping sides. Subsidence can occur in woodland, farmland or industrial areas. Most frequently this type of ground distortion is regarded as detrimental to the natural environment. However, the few studies conducted so far suggest that subsidence basins are unique enclaves which facilitate the development of new ecological systems thereby contributing to the biodiversity of such areas (Bradshaw, 2000; Banaszak, 2002).

The aim of this paper is to evaluate the diversity of Thysanoptera against the diversity of the plant cover around a water basin in a subsidence located in a wooded area in relation to the forest complex.

\footnotetext{
* Corresponding author; e-mail: edyta.sierka@gmail.com
} 


\section{Materials and Methods}

The investigated area is situated in the centre of the Silesian Upland (southern Poland). Upper Carboniferous rocks are the main geological structures of this area and are essential to the economy of the region (Kalin, 2004). They are overlaid by a thick layer of postglacial matter, such as sand, gravel and clay. The diversity, distribution and condition of forest communities, which cover approximately $20 \%$ of the area, are closely connected with the character of habitats and with the type and intensity of human impact (Celiński et al., 1991).

For a detailed analysis of the biodiversity of the thysanopteran fauna an area near a water basin was selected, which was formed in a subsidence located in a wooded area (habitat Tilio-Carpinetum, with Carex brizoides) at Sosnowiec, Kazimierz Górniczy district (South Poland) (Fig. 1). This water basin, formed 15 years ago, covers an area of about 12 ha and is beginning to be overgrown, especially with Phragmites australis.

In the period 2006-2007 thrips were collected with a sweep net along transects which ran radially from the centre of the basin in eight directions (Fig. 2).

The transects were $2 \mathrm{~m}$ wide and at most $25 \mathrm{~m}$ long (the basics plot $4 \mathrm{~m}^{2}$ ). Thrips were stored in AGA fluid. For mounting thrips on slides the Bisevac (1997) method was used. The adult specimens were identified to the species level (females and males) on the

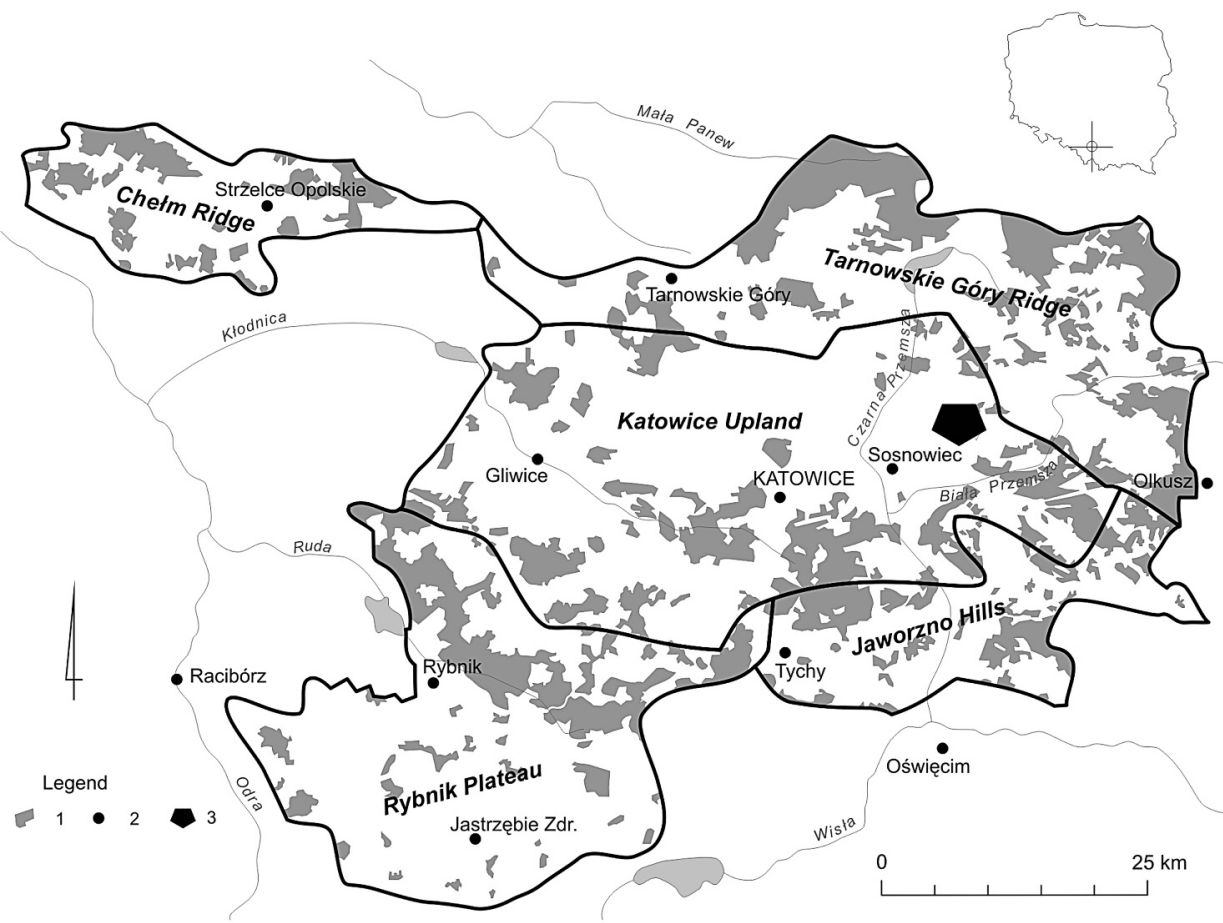

Fig. 1. Localisation of study area. 1 - forests; 2 - towns; 3 - study plots 


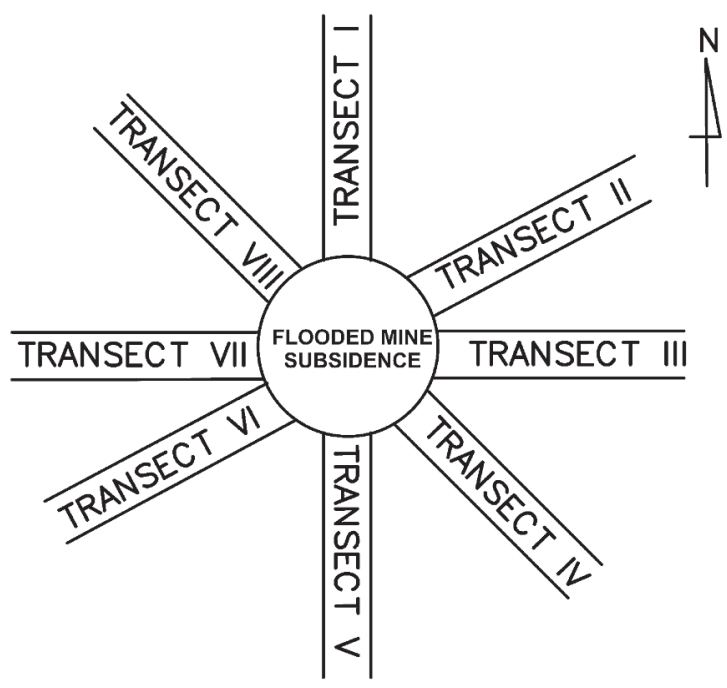

Fig. 2. Scheme of distribution of study transects

basis of Schliephake and Klimt (1979) and zur Strassen (2003). Names of species and their systematic arrangement follow Fauna Europaea (www.faunaeur.org; 15.08.2007).

Plants and the estimated decimal percentage of coverage were recorded in squares of $4 \mathrm{~m}^{2}$. The nomenclature of syntaxonomic units is according to Matuszkiewicz (2001) and of vascular plants after Mirek et al. (2002). An area of $400 \mathrm{~m}^{2}$ in the immediate vicinity of the basin was investigated and an area of the same size located in the forest.

Various indices of species richness and species diversity for Thysanoptera and plants were applied. Species richness referred to the number of species in the study plot for thrips and the percentage cover for plants. Additionally Simpson's species diversity coefficient was calculated (Simpson, 1949) from the following formula:

$$
\delta=\sum_{i=1}^{s^{*}} p_{i}^{2}, \text { where } p_{i}-\text { fractional contribution of species in the community }
$$

Alpha diversity ( $\alpha$-diversity) is the biodiversity within a particular area and is measured by e.g. counting the number of species. Alpha diversity was defined as the average percentage cover of plant and average number of thrips species recorded in a subplot (for the total of 8 transects) within a study plot (Schluter and Ricklefs, 1993).

$$
\alpha=\sum_{i=1}^{i=100} s / 100 \text {, where } s \text { is the number of species (the percentage cover). }
$$

Beta diversity ( $\beta$-diversity) is a measure of biodiversity which relies on a comparison of species diversity across ecosystems. This involves comparing the number of species that are unique to each of the ecosystems. The Sørensen index is a very simple measure of beta diversity, ranging from a value of 0 , where there is no species overlap between the 
communities, to 1, where exactly the same species are found in both communities (Schluter and Ricklefs, 1993). To determine the similarity of species composition in two analyzed areas, Sørensen's coefficient $(\beta)$ was used, calculated from the following formula (Sørensen, 1948):

$$
\beta=\frac{2 C}{A+B} \text {, where } A-\text { the total number of species recorded in the first community, }
$$

$B$ - the total number of species recorded in the second community, and $C$ - the number of species common to both communities.

The results of the comparison of subplots and plots are given in figures. Correlation coefficients were derived by Spearman's test with Statistica 5.0. software, $\mathrm{p}<0.05$ was considered to be statistically significant.

\section{Results}

In the studied area a total of 50 species of Thripidae and 6 species of Phlaeothripidae were found (Table 1). The total number of plant species in both areas was 118; 91 in the forest ecosystem with the enclave of subsidence basin and 52 in the forest complex. Twenty-five plant species were reported from both ecosystems. Species diversity measured by Simpson's coefficient in the subsidence basin area and the forest complex is presented in Figs 3, 4 for Thysanoptera and plants, respectively. The differences in species diversity between these two ecosystems were significant for plants $(p=0.021)$ and thrips $(p=0.037)$.

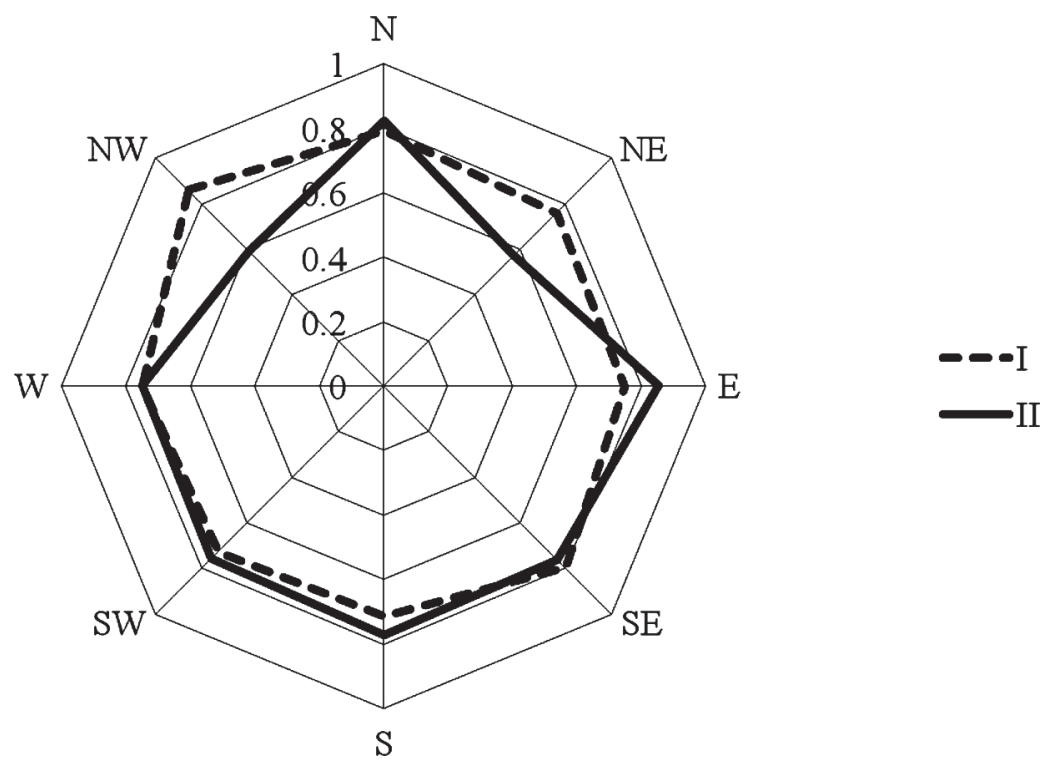

Fig. 3. Simpson's species diversity coefficient for thrips; I - water ecosystem; II - wood ecosystem 
Table 1

The list of thrips species in the studied water and wood ecosystem

\section{AEOLOTHRIPIDAE}

Aeolothrips albicinctus Haliday

Aeolothrips intermedius Bagnall

Aeolothrips melaleucus Haliday

Aeolothrips vittatus Haliday

\section{THRIPIDAE}

Anaphothrips atroapterus Priesner

Anaphothrips badius Williams

Anaphothrips euphorbiae Uzel

Anaphothrips obscurus Müller

Aptinothrips elegans Priesner

Aptinothrips rufus Haliday

Aptinothrips stylifer Trybom

Baliothrips dispar Haliday

Chirothrips aculeatus Bagnall

Chirothrips ambulans Bagnall

Chirothrips manicatus Haliday

Chirothrips hamatus Bagnall

Dendrothrips degeeri Uzel

Frankliniella intonsa Trybom

Frankliniella tenuicornis Uzel

Iridothrips iridis Watson

Limothrips cerealium Haliday

Limothrips denticornis Haliday

Mycterothrips latus Bagnall

Mycterothrips salicis Reuter

Odontothrips biuncus John

Odontothrips loti Haliday

Oxythrips ajugae Uzel

Oxythrips bicolor Reuter
Platythrips tunicatus Haliday

Rubiothrips ferrugineus Uzel

Rubiothrips silvarum Priesner

Rubiothrips validus Karny

Stenothrips graminum Uzel

Taeniothrips atratus Haliday

Taeniothrips inconsequens Uzel

Tenothrips frici Uzel

Thrips alni Uzel

Thrips angusticeps Uzel

Thrips brevicornis Priesner

Thrips euphorbiae Knechtel

Thrips flavus Schrank

Thrips fuscipennis Haliday

Thrips major Uzel

Thrips minutissimus Linnaeus

Thrips physapus Linnaeus

Thrips pillichi Priesner

Thrips tabaci Lindeman

Thrips trehernei Priesner

Thrips validus Uzel

Thrips vulgatissimus Haliday

PHLAEOTHRIPIDAE

Haplothrips acanthoscelis Kamy

Haplothrips aculeatus Fabricius

Cephalothrips monilicornis Reuter

Haplothrips hukkineni Priesner

Haplothrips leucanthemi Schrank

Neoheegeria verbasci Osborn

All species were found in both ecosystems, except $A$. melaleucus, D. degeeri (both missing from the wood ecosystem), C. hamatus, I. iridis, B. dispar and N. verbasci (these four are missing from the water ecosystem). 


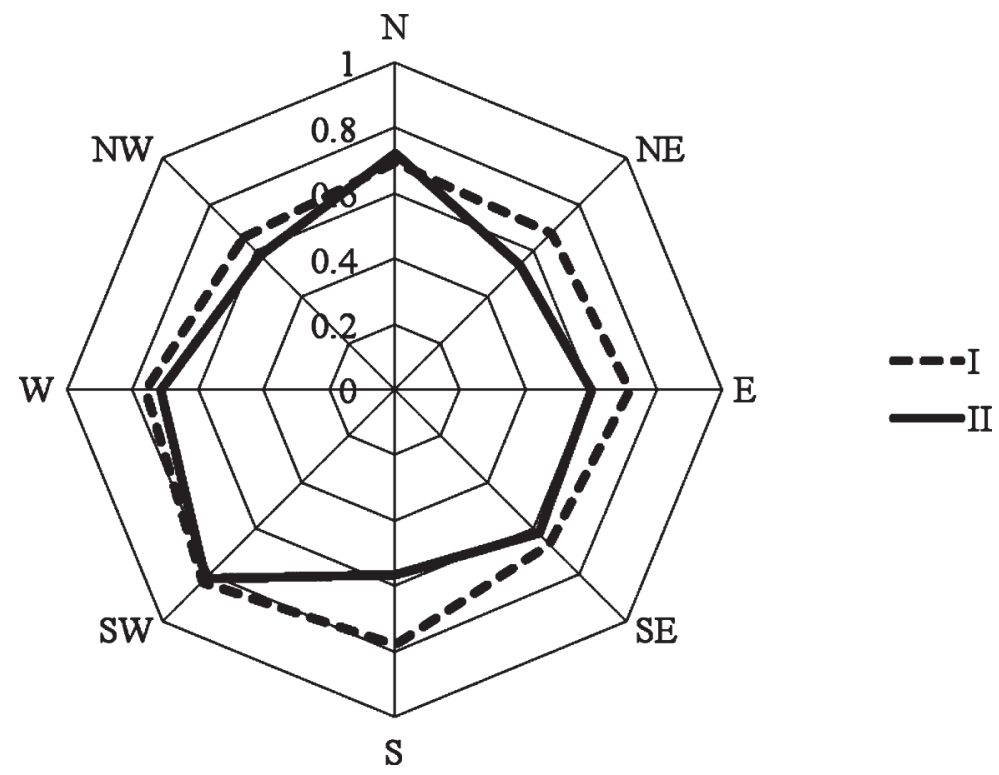

Fig. 4. Simpson's species diversity coefficient for plants; I - water ecosystem; II - wood ecosystem

Alpha diversity, which shows the tendencies in species diversity for both Thysanoptera and plants, is markedly higher for the area surrounding the water basin than for the forest complex (Figs 5, 6). The relationships between alpha diversity of plants $(p=0.014)$ and thrips $(p=0.042)$ in these two ecosystems are significant.

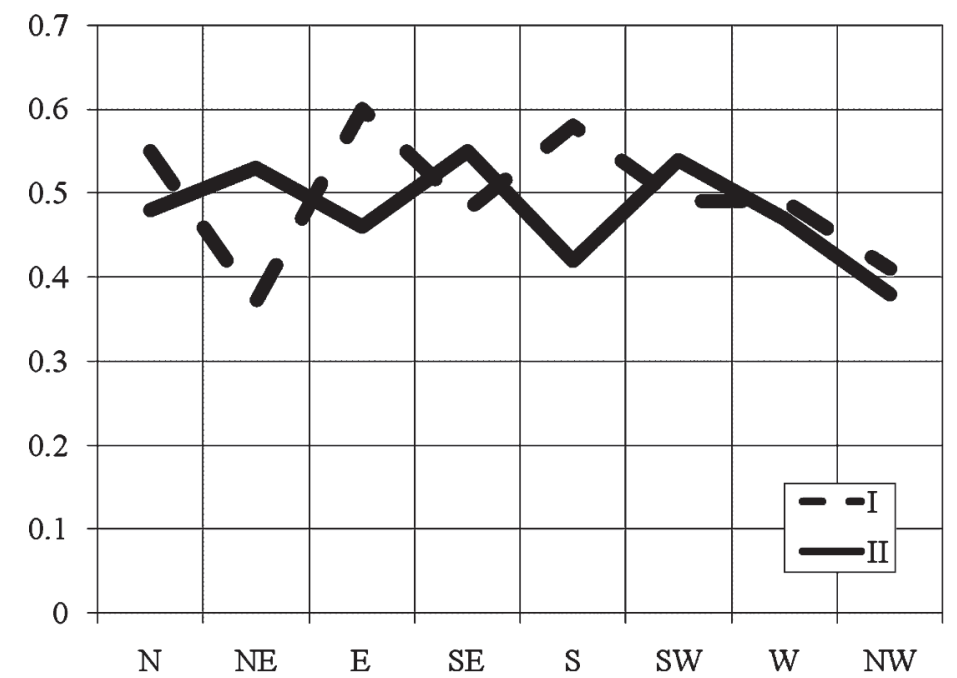

Fig. 5. Alpha diversity for thrips; I - water ecosystem; II - wood ecosystem 


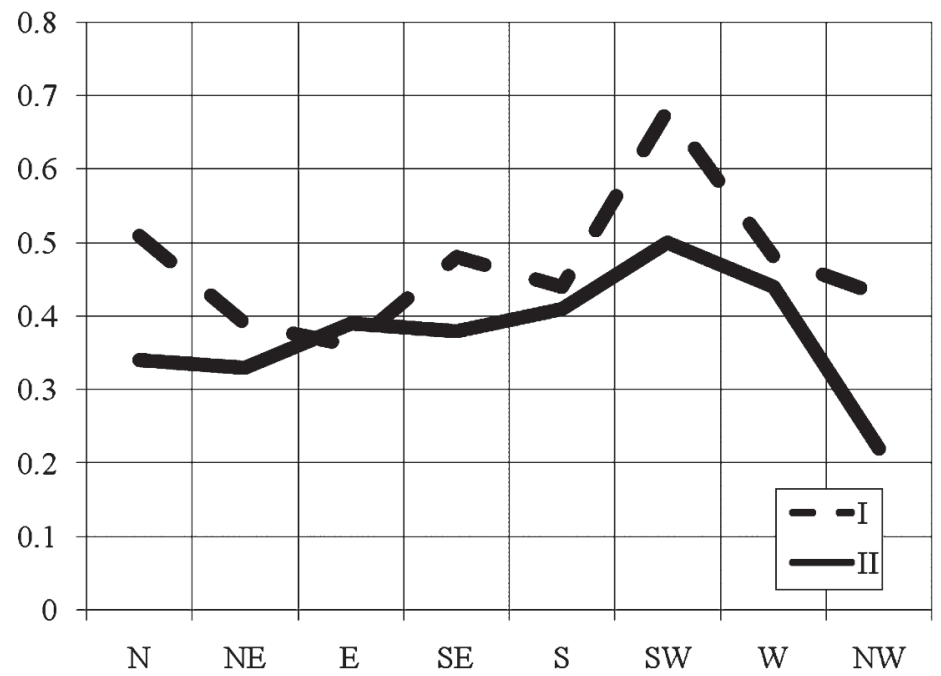

Fig. 6. Alpha diversity for plants; I - water ecosystem; II - wood ecosystem

The analysis of species richness (the number of species within the two ecosystems) shows that the species composition for plants around the water basin and in the forest differs considerably $(\beta=0.35)$, and that these differences are not so strongly marked for thrips communities $(\beta=0.94)$.

Moreover, Chirothrips hamatus Bagnall, Iridothrips iridis (Watson), Baliothrips dispar (Haliday), and Neoheegeria verbasci Osborn were reported only from the water basin ecosystem. By contrast, Aeolothrips melaleucus Haliday and Dendrothrips degeeri Uzel occurred only in the forest ecosystem.

The relationships between the diversity of plants and the diversity of thrips in the flooded mine subsidence ecosystem is significant $(p=0.037)$, and in the forest ecosystem is not significant $(p=0.741)$.

\section{Discussion}

Anthropogenic water basins in the mining landscape play an important role in the composition of species and biocenotic diversity in ecotone zones, where water and forest phytocenoses meet and where unique habitat conditions evolve for plants of varied preferences (Krahulec and Lepš, 1993). These plants, in turn, offer specific conditions for certain groups of animals, as shown in the present research.

Thus, disturbing land appears to be more harmful for humans than for other species, which adapt relatively easily to new environmental conditions. Ultimately, anthropogenic water basins contribute to the species diversity (Stalmachová, 1997).

The presented results show distinct differences between the ecosystems of the forest complex and the anthropogenic water basin in terms of both plant and thrips life. Species 
richness values for the studied insect group, expressed by Simpson's coefficient and Sørensen index, are similar in both ecosystems. However, the subsidence area is marked by the presence of species that prefer humid habitats (C. hamatus, I. iridis, and B. dispar). Worth noting is the massive occurrence of I. iridis, which is monophagous and connected only with Iris pseudacorus, growing on the edges of the subsidence.

With respect to the plant diversity, considerable differences between the two ecosystems probably result from the disturbance of the forest habitat by the massive occurrence of Carex brizoides. This type of transformation of forest phytocenosis substantially impoverishes its plant species composition (Chmura and Sierka, 2007), which may influence the results. At the same time, the subsidence basin enhances the diversity of the habitat conditions and therefore prevents Carex brizoides from spreading (excessive humidity), while giving opportunities for many species connected with humid habitats, e.g. Phragmitetea class and ecotone species. This is showed in the low Sørensen's coefficient for plants $(\beta=0.35)$, but not for thrips, which is close to $1(\beta=0.94)$.

Markedly lower values of species diversity, both for plants and thrips, were observed in the NW transect, which results very probably from the vicinity of the asphalted main road 1 and its direct impact on vegetation and indirect impact on thrips fauna, for example from the remains of building material at the foot of a steep slope of the road embankment.

The biological profile of subsidence basins is now limited to the few existing studies concerned, each with selected elements present in the mining areas (Buszman et al., 1993; Tokarska-Guzik and Rostański, 1996), so it cannot serve as the immediate point of reference for the present results. Therefore, further investigations of this type (faunisticfloristic) seem necessary in areas of anthropogenic water ecosystems to provide a basis for evaluation of the diversity of such ecosystems, to propose responsible land management (Kalin, 2004) and also to prevent hasty recultivation by filling in the basins with waste rock. The latter approach is cheap and attractive in order to get rid of industrial waste, but is not acceptable for ecologically justifiable management.

\section{Acknowledgement}

The work is partly financed by the Ministry of Science and Higher Education for 2007-2009 as a research project.

\section{Literature}

Banaszak, J. (2002): Wyspy środowiskowe. Bioróżnorodność i próby typologii. Wyd. Akademii Bydgoskiej, Bydgoszcz, pp. 302.

Bisevac, L. (1997): A new method for mounting thrips (Thysanoptera) on slides. Austr. J. Entomol. 36, 220.

Bradshaw, A. D. (2000): The use of natural processes in reclamation. Advantages and difficulties. Landscape and urban planning 51, 89-100.

Buszman, B., Parusel, J. B. and Świerad, J. (1993): Przyrodnicza wartość leśnych stawów w Tychach Czułowie przeznaczonych na zwałowisko odpadów kopalni węgla kamiennego. Kształtowanie Środowiska Geograficznego i Ochrona Przyrody na Obszarach Uprzemysłowionych i Zurbanizowanych. WBiOŚ, WNoZ, U.Śl. Katowice, Sosnowiec, 8, 10-15. 
Celiński, F., Szczypek, T. and Wika, S. (1991): Waloryzacja szaty leśnej województwa katowickiego na tle przeobrażeń niektórych elementów środowiska geograficznego. In: Zmiany środowiska geograficznego w warunkach silnej antropopresji (wybrane zagadnienia) cz.3. UŚl., WNoZ, Fundacja Ekologiczna "Silesia", pp. 1-145.

Chmura, D. and Sierka, E. (2007): The invasibility of deciduous forest communities after disturbance: A case study of Carex brizoides and Impatiens parviflora invasion. Forest Ecology and Management 242, 487-495.

Kalin, M. (2004): Passive mine water treatment: The correct approach? Ecological Engineering 22, $299-304$.

Krahulec, F. and Lepš, J. (1993): The migration of vascular plants to a new water reservoir: geographic relationships. Preslia 65, 147-162.

Matuszkiewicz, W. (2001): Przewodnik do oznaczania zbiorowisk roślinnych Polski. Vademecum Geobotanicum. PWN, Warszawa, pp. 536.

Mirek, Z., Piękoś-Mirkowa, H., Zając, A. and Zając, M. (2002): Flowering plants and pteridophytes of Poland checklist. PAN, Warszawa, pp. 421.

Schliephake, G. and Klimt, K. (1979): Thysanoptera. Die Tierwelt Deutschlands. Gustav Fisher Verlag, Jena, pp. 477.

Schluter, D. and Ricklefs, R. E. (1993): Species diversity: an introduction to the problem. In: R. E. Ricklefs and D. Schluter (eds). Species Diversity in Ecological Communities. Univ. of Chicago Press, Chicago, Illinois, USA, pp. 426-449.

Simpson, E. H. (1949): Measurement of diversity. Nature 163, 688-691.

Sørensen, T. A. (1948): A method of establishing groups of equal amplitude in plant sociology based on similarity of species content, and its application to analyses of the vegetation on Danish commons. K. dan Vidensk, Selsk. Bil. Skr. 5, 1-34.

Stalmachová, B. (1997): Watered depressions as ecological phenomena in regions affected by mining activities. In: B. Stalmachová (ed.): Proc. Mine Planning and Equipment Selection 1997. Balkema, Rotterdam, pp. 979-984.

Strassen, R. zur (2003): Die terebranten Thysanopteren Europas. Goecke and Evers, Keltern, pp. 277.

Tokarska-Guzik, B. and Rostański, A. (1996): Rola zatopisk (zalewisk) pogórniczych w renaturalizacji przemysłowego krajobrazu Górnego Śląska. Przegl. Przyr. VII., 267-272. 